\title{
Retracted: Influence of Magnesium Substitution on Thermal and Electrical Properties of NiCuZn Ferrites for Microinductor Core Applications
}

\author{
Physics Research International \\ Received 2 October 2014; Accepted 2 October 2014; Published 30 October 2014 \\ Copyright (C) 2014 Physics Research International. This is an open access article distributed under the Creative Commons \\ Attribution License, which permits unrestricted use, distribution, and reproduction in any medium, provided the original work is \\ properly cited.
}

The paper titled "Influence of magnesium substitution on thermal and electrical properties of $\mathrm{NiCuZn}$ ferrites for microinductor core applications" [1], published in Physics Research International, has been retracted as it is found to contain a substantial amount of material from the paper "Studies on AC and DC electrical conductivity and thermoelectric power of NiMgCuZn ferrites" already published in International Journal of Nanoparticles, vol. 3, no. 4, pp. 349366, 2010.

\section{References}

[1] M. Venkata Ramana, N. Ramamanohar Reddy, and K. V. Siva Kumar, "Influence of magnesium substitution on thermal and electrical properties of NiCuZn ferrites for microinductor core applications," Physics Research International, vol. 2012, Article ID 861690, 8 pages, 2012. 